\title{
Light and Electron Microscopic Studies on the Possible Protective Effect of Ginger on the Gastric Fundic Mucosa of Adult Male Albino Rats Treated with 5- Fluorouracil
}

\author{
Manar A. Bashandy and Dalia A. Noya
}

Anatomy and Histology Department, Faculty of Medicine, Menoufia University, Egypt

\begin{abstract}
Introduction: 5-fluorouracil is a potent antimetabolite chemotherapeutic medication used for treatment of various malignancies . Using this agent result in toxic effect mainly in the lining of digestive tract. To ameliorate 5 FU toxic effect ginger was implicated in this study.

Aim of the Work: To evaluate the microscopic effect of 5-fluorouracil on gastric fundus mucosa in rat models . and to study the possible beneficial role of ginger in the ameliorations of these changes.

Material and Methods: Forty-eight adult male albino rates were divided into four groups: group I (control), group II received ginger orally in a dose of $200 \mathrm{mg} / \mathrm{kg} /$ day , group III received 5-fluorouracil $(15 \mathrm{mg} / \mathrm{kg})$ intraperitoneally and group IV received $5 \mathrm{FU}$ and Ginger as previous doses for 5 days. The fundic part of stomach was excised and subjected to light and electron microscopic studies.

Results: In 5 FU treated group, the fundic gastric mucosa showed multiple areas of tissue loss, congested dilated blood vessels and extravasated red blood cells and mononuclear infiltration were seen between fundic gland cells. Parietal cells showed ballooned appearance, vacuolated cytoplasm, and pykontic nuclei. PAS/ Alcian blue stained sections showed marked reduction in both alcian blue and PAS positive reaction. There was strong positive cytoplasmic reaction in the apical and middle parts of the fundic glands for caspase 3 while large number of parietal cells were stained positive for Cox 2 . These histological findings were improved after ginger administration. Histomorphometric study revealed significant weight reduction, increased mucosal ulcer depth, decreased mucosal thickness and increased number of parietal cells in $5 \mathrm{FU}$ treated group when compared to control group.

Conclusion: 5FU causes gastric damage in rat model. Ginger supplementation could be used to alleviate the damaging pathological effect on gastric fundus.
\end{abstract}

Received: 18 February 2019, Accepted: 14 July 2019

Key Words: 5 fluouracil, Ginger, rat, stomach.

Corresponding Author: Dalia A. Noya, MD, Anatomy and Histology Department, Faculty of Medicine, Menoufia University, Menoufia, Egypt, Tel.: +20 1068464307, E-mail: dalia_noya@yahoo.com

ISSN: 1110-0559, Vol. 43, No. 1

\section{INTRODUCTION}

Chemotherapy includes the use of cytotoxic agent to eradicate neoplastic cancer cells in different organs ${ }^{[1]}$. These drugs had different routes of administration with the main purpose of reaching therapeutic level in blood stream $^{[2]}$

5-fluorouracil is a potent antimetabolite chemotherapeutic medication. It is commonly implicated for treatment of various malignancies such as breast, colorectal, liver, skin, head and neck cancers $^{[3]}$. It is activated by thymidine phosphrylase enzyme into fluoro - deoxyuridylate which is capable of suppression of thymidylate synthase, resulting in direct inhibition of DNA synthesis. Additionally, it had cytotoxic effect which exerted on cancer cells by preventing RNA synthesis ${ }^{[4]}$. 5-fluorouracil acts on both rapidly growing neoplastic cancer cells and normal healthy cells without differentiating between them ${ }^{[5]}$. Using this agent results in toxic adverse effect such as myelosuppression, cardiotoxicity, neurotoxicity, vomiting, diarrhoea, mucositis manifestations ${ }^{[6]}$. Mucositis symptoms appear in the form of abdominal pain, bleeding and dysphagia which can end with life threatening septicaemia ${ }^{[7]}$. Zingiber officinale Roscoe (ginger) is an herbal supplement used in traditional medicine. It was used for therapeutic purpose in many conditions as nausea, vomiting, stomach-aches, motion sickness and arthritis ${ }^{[8]}$. Ginger is a plant of family Zingiberaceae. Its dried form contains active constituents of about $1-4 \%$ of volatile oils ${ }^{[9]}$. It contained three active chemical ingredients such as gingerol, zingerone and shogaol ${ }^{[10]}$. These compounds have been proved to have 
numerous beneficial effects including anti-carcinogenic, anti-inflammatory, antioxidant, spasmolytic and antiulcerogenic properties ${ }^{[11,12]}$.

Some previous studies had reported that, ginger had protective effects in aspirin induced gastric ulcers ${ }^{[13]}$ and had a role in protection of indomethacin- (one of the nonsteroidal anti -inflammatory drugs) (NSAID) induced gastric damage ${ }^{[9]}$

Keeping all the above in mind, the present study had been carried out to evaluate the microscopic hazardous effect of 5-fluorouracil on gastric fundus mucosa using male rats model. It also elucidates the possible beneficial role of ginger in the ameliorations of these changes.

\section{MATERIAL AND METHOD}

\section{Animals}

For this study, forty-eight adult male albino rates were selected from breeding animal house present in Faculty of Medicine, Menoufia University, weighting (180-200 gm). They were housed in cages under hygienic situation and kept at room temperature. The rat diet consisted of standard food and tap water ad labium.

\section{Drugs and Chemicals}

\section{5-flurouracil}

Vial contained $500 \mathrm{mg} / 10 \mathrm{ml}$ obtained from EIMC United Pharmaceuticals Company, Bader city, Cairo - Egypt (A.R.E). In the resulting solution, each $1 \mathrm{ml}$ contained $50 \mathrm{mg}$ 5-FU which was diluted in $4 \mathrm{ml}$ distilled water for the calculated dose for the use immediately just subsequent to dilution.

\section{Ginger}

Zingiber officinale Roscoe (ginger) was obtained in the form of crude dried materials from a local hypermarket from Menoufia, Egypt. The estimated dose was suspended in $4 \mathrm{ml}$ of $1 \%$ carboxymethylcellulose (was obtained from Sigma-UK) in water.

\section{Experimental Design}

The experiment was designed according to guidelines approved by Ethical Committee of Menoufia University. The rats were randomly divided into four groups of equal number (12 animals in each)

Group I: was served as control group. In this group, rats were received $1 \%$ carboxymethylcellulose in water (vehicle) orally during the duration of experiment. It was obtained from (Sigma - Adrich, Poole, UK). Each animal received $0.8 \mathrm{ml}$ carboxymethylcellulose (1\%).

Group II: (Ginger treated group) rat administered ginger powder in a dose of $200 \mathrm{mg} / \mathrm{kg}$ body weight dissolved in $4 \mathrm{ml}$ of $1 \%$ carboxymethylcellulose in water for 5 days $^{[13]}$. Each animal received $0.8 \mathrm{ml} /$ day for 5 days.

Group III: (5-fluorouracil treated group) rats received 5-fluorouracil $(15 \mathrm{mg} / \mathrm{kg})$ injected intraperitoneal for
5 days $^{[1]}$. After dilution each animal received $0.3 \mathrm{ml}$ of 5 -fluorouracil.

Group IV: (Ginger and 5-fluorouracil treated group) animals in this group were administered ginger powder dissolved in carboxymethylcellulose in water in a same dose as group II followed by intraperitoneal injection of 5-fluorouracil of same dose as group III for same experimental duration.

On day six, 24 hours after the final dose of drug intake, using an electronic balance, the rats were weighted in grams. They were sacrificed by using ether. From each animal, the fundic part of stomach was selected and excised using scissors. Exposure of the mucosal surface of the stomach was obtained by incising the greater curvature. The gastric tissues were subjected to the subsequent studies:

\section{1- Light microscopic study}

I- Hematoxylin and Eosin stain: The gastric specimens were fixed in $10 \%$ formol saline then processed to get paraffin blocks. From each block, sections of $5 \mu \mathrm{m}$ thickness were obtained and subjected to hematoxylin and eosin stain to demonstrate the general gastric architecture ${ }^{[14]}$.

II- Histochemical stain: Paraffin gastric sections were subjected to Alcian blue stain for detection of mucin then the sections were stained with (PAS) Periodic acid shief stain to reveal the glycogen content ${ }^{[14]}$.

III- Immunohistochemical stains: For the present study, from each paraffin block, tissue sections of $5 \mu \mathrm{m}$ thicknesses were obtained and subjected to immunostain using antibodies for cyclooxygenase 2 and caspase 3 . Briefly, sections were fixed on glass slides mounted by pol-L-lysin then heated overnight at $37^{\circ} \mathrm{C}$ subsequently deparaffinized using xylene. Later, sections were rehydrated in descending grades of alcohol. To block endogenous peroxidase, the slides were heated in microwave oven using hydrogen peroxide solution (3\%) for 5 minutes. The slides were primarily treated with trypsin solution $(1 \mathrm{mg}$ in $150 \mathrm{ml}$ Tris- $\mathrm{HCl}, 0.05 \mathrm{M}, \mathrm{pH} 7.6$ ) for $15 \mathrm{~min}$ at room temperature. Antigen retrieval technique using citrate buffer $(0.01 \mathrm{M}, \mathrm{pH}$ 6.0) and microwave heating was performed. The tissues were incubated overnight at $41^{\circ} \mathrm{C}$ with cyclooxygenase 2 antibodies using COX-229 Mouse monoclonal antibodies diluted as 1:100 obtained from Cayman Chemical Co. (Ann Arbor, MI, USA) ${ }^{[15]}$. Regarding to caspase 3 immunostain, caspase-3 expression was revealed by use of a peroxidaseconjugated rabbit monoclonal antibody $\operatorname{IgG}$ (Cell signaling Technology, Ipswich, MA) at dilution 1:200 ${ }^{[16]}$.

Sections were washed and incubated at room temperature for 30 minutes with streptavidin biotin peroxidase complex obtained in the form of (StreptABComplex, Dako, and Carpinteria, CA, USA). Finally, diaminobenzidine $\mathrm{DAB}$ peroxidase tablet was utilized as chromogen. Both caspase 3 and cox 2 immunostains were counterstained with hematoxylin stain. For obtaining negative controls, primary antibodies were by omitted. Normal lymphoid tissue was used as positive control[16]. 


\section{2- Electron microscopic study}

For scanning electron microscopy (SEM), the fundic gastric specimens were cut into small pieces of about $1 \mathrm{~cm}$ length. Each specimen was immersed in $1 \%$ paraformaldehyde and $2.5 \%$ buffered glutaraldehyde in $0.1 \mathrm{M}$ phosphate buffer at $\mathrm{pH} 7.2$ for 2 hours at $4{ }^{\circ} \mathrm{C}$. Small pieces of about $5 \times 5 \mathrm{~mm}$ were obtained by cutting the fundic gastric specimens into smaller pieces. Post fixation in $1 \%$ Osmic acid for (30min). These pieces were washed three times by $0.1 \mathrm{M}$ phosphate buffer (ten minutes each) then kept in $1 \%$ osmic acid for 30 minutes. Later, Washing the specimens three times with PBS (10 min. each), then dehydrated with ascending series of ethyl alcohol $(30,50$, $70,90 \%$ and absolute alcohol) infiltrated with acetone, each concentration for $30 \mathrm{~min}$. Moreover, In SEM, samples were dried in SPI supplies ${ }^{\circledR}$, critical point drying machine using liquid $\mathrm{CO} 2$. Then mounted on aluminum stubs, coated with gold in a SPI- Module TM Vac/ Sputter. Finally, The gold coated pieces were examined and photography using JEOL, JSM- 5200 LV scanning electron microscope, Japan present in Electron microscope Unit, Faculty of Medicine, Tanta University ${ }^{[17,18]}$.

\section{3- Histomorphometric study}

Haematoxylin and eosin stained photomicrographs of x 200 magnification were used for measurements. Each photomicrograph was imported and opened in $\mathrm{J}$ image software (J 1.47., Java source, USA) for histomorphometric analysis. Each photomicrograph was imported, opened in $\mathrm{J}$ image software and calibrated in micron for measurement of gastric mucosa thickness ${ }^{[19]}$ and gastric ulcer depth. Cyclooxygenase 2 stained photographs at magnification of $\times 200$ were used for calculation and measurement of immune-positive parietal cells. For each measured parameter, five non overlapped fields from each slide were used. Five slides were selected from each animal. The mean for each animal was calculated then the mean for each group was estimated.

\section{Statistical analysis}

In each group, the numerical data in the form of rat mean weight in gram, fundic mucosal thickness in microns, ulcer depth in micron and parietal cells number were estimated and expressed as mean $\pm \mathrm{SD}$. One way ANOVA test was used to calculate the statistical differences between the groups using Statistical Package for the Social Science Software, version 11 (SPSS, Inc., Chicago, USA.) on an IBM compatible computer. In all statistical analysis $P<0.05$ was taken as the level of significance ${ }^{[20]}$

\section{RESULTS}

\section{Light microscopic results}

Group I (the control group): $\mathrm{H}$ and $\mathrm{E}$ stained sections of the fundic mucosa of the stomach was formed of surface columnar epithelial cells, lamina propria and muscularis mucosa. The lamina propria was occupied by numerous, straight, tubular fundic glands which were perpendicular to the surface and separated by minimal amounts of loose connective tissue (Figure 1). The fundic glands consisted of ismuth which open to the surface by short pit, middle part called neck and basal part. The lining epithelium was formed of mucous secreting columnar cells with pale cytoplasm and basal oval nuclei. Mucous neck cells with flat basal nuclei and pale foamy cytoplasm. Parietal cells appeared large polyhedral with acidophilic cytoplasm and central rounded nuclei with prominent nucleoli. The chief cells (peptic) were located basally and appeared low columnar with basophilic cytoplasm and basally located nuclei, giving the basal part of the gland its dark appearance (Figure 2)

PAS/alcian blue stained sections showed strong positive alcian blue reaction in the region of mucous neck cells with faint reaction on the rest of the gastric gland's cells. The surface columnar mucous secreting cells had strong positive PAS reaction. Also thick prominent mucous barrier appeared covering the surface (Figure 3)

On Immunohistochemical staining for Caspase 3 the sections showed weak to negative cytoplasmic Caspase 3 reaction all over the cells of the glands (Figure 4). Mild cytoplasmic immunoreactivity for Cox 2 was seen in few numbers of the parietal cells in the fundic glands of this group (Figure 5)

Group II (ginger treated group): On examination of sections under light microscopy; the fundus of the stomach after ginger administration showed similar picture to that of group I (control), as it didn't reveal any histopathological changes.

Group III (5 - fluorouracil treated group): Microscopic examination of HandE stained sections of the fundic gastric mucosa showed variable degrees of mucosal lesions. Some sections revealed multiple areas of tissue loss with widening between the fundic glands. Congested dilated blood vessels were noticed between fundic gland cells and also in the lamina propria (Figure 6). Other sections showed exfoliation of the superficial gastric epithelium. Parietal cells showed ballooned appearance, vacuolated cytoplasm, and darkly stained pykontic nuclei. While the basal part of the gland was disorganized, dilated with thinning of its lining epithelium. Chief cells reveled different appearances, some appeared flat with flat deeply stained nuclei, others showed foamy vacuolated cytoplasm (Figures 7 and 8).Some glands in the basal part appeared atrophied. Mononuclear cellular infiltrate in the lamina propria were seen in some sections. Others showed aggregated lymphoid cells in the form of follicles in lamina propria and extending to the basal part of the fundic gland (Figures 9 and 10)

PAS/ Alcian blue stained sections showed marked reduction in both alcian blue and PAS positive reaction (Figure 11a). In some area, an apparent alcian blue weak positive reaction was seen in the middle part of the glands (Figure 11b) 
For the Immunohistochemical staining for group III, it reveled strong positive cytoplasmic reaction in the apical and middle parts of the fundic glands and weak to moderate cytoplasmic reaction in the basal part for caspase 3 (Figure 12). On examination of Cox 2 sections, it showed strong cytoplasmic immunoreactivity for Cox 2 in large numbers of parietal cells in comparison to control group (Figure 13).

Group IV (5-fluorouracil and ginger treated): Microscopic examination of HandE stained sections showed that the fundic mucosa appeared more or less normal compared with control group. The mucosa appeared intact with regularly arranged fundic glands. The lining cells of the fundic gland were composed of surface columnar cells that appeared normal concerning their cytoplasm and nuclei (Figure 14). Parietal cells were seen with their rounded shape, acidophilic cytoplasm and central vesicular nuclei. Mucous neck cells occupying the middle part of the gland with their characteristic basal flattened nuclei and pale foamy cytoplasm were also seen. Only few affected parietal cells and little extravasated blood cells were seen (Figure 15). The basal part of the fundic gland reveled chief cells with apical acidophilia and basal basophilia in their cytoplasm. Also few mononuclear cellular infiltration and congested vessel were noticed (Figure 16)

Examination of PAS/ alcian blue stained sections revealed apparently normal mucous barrier. PAS positive reaction in the apical part of the fundic mucosa was noticed, whereas the mucous neck cells showed positive alcian blue reaction with faint reaction all over the rest of the gland (Figure 17)

By Immunohistochemical staining for Caspase 3, the sections of fundic glands revealed weak to negative cytoplasmic Caspas 3 reaction all over the gland's cells (Figure 18). Strong cytoplasmic immunoreactivity for Cox 2 was noticed in a large numbers of parietal cells compared to group I (Figure 19).

\section{Electron microscopy results}

Scanning electron microscopic (SEM) photograph of the fundus of the stomach of the control group (group I) showed intact mucosal surface which was interrupted by small opening of gastric pits, surrounded by mucous surface cells .Masses of mucous aggregation were seen scattered on the mucosal surface (Figure 20).

Scanning electron microscopic photograph of the fundus of the stomach of the ginger treated group (groupII) showed no difference from the control group (group I).

Scanning electron microscopic photograph of the fundus of the stomach of the 5-fluorouracil treated group (group III) showed ulcer extending deep in the mucosal layer. Complete shedding of the surface mucosal cells leaving the walls and the opening of gastric pits in the picture of honeycomb (Figures 21 and 22). Also necrotic tissue emerging from dilated gastric pits and scattered on the surface was noticed. The ulcer was seen extending deep to the level of muscularis mucosa (Figure 23).

Scanning electron microscopic photograph of the fundus of the stomach of the 5-fluorouracil and ginger treated group (group IV) showed apparently normal architecture of gastric mucosal surface (Figure 24).

\section{Morphometric and Statistical Results}

Morphometric analysis showed high significant reduction $(P<0.001)$ in the final animal body weight in group III (after administration of 5-fluorouracil) as compared to group I and group II. Also showed significant reduction $(P<0.05)$ in the final body weight in group IV (after intake of both 5fluorouracil and ginger) as compared to group I and group II. There was a significant increase $(P<0.001)$ in final body weight in group IV as compared to group III. (Table 1 and graph 1 )

Highly significant increase $(P<0.001)$ in depth of fundic gastric mucosal ulcers in group III when compared to group I and II and non-significant increase $(P>0.05)$ in group IV when compared to group I and II was found. Also highly significant decrease in the depth of mucosal ulcer $(P<0.001)$ was found in group IV when compared to group III. (Table 2 and graph 2).

As revealed in (Table 3 and graph 3 ), a highly significant reduction $(P<0.001)$ in mucosal thickness of stomach fundus of 5-fluorouracil treated rats (group III) compared to group I and II. While, non-significant difference in fundic gastric mucosal thickness was recorded in group IV when compared to group I and II. A highly significant increase in the fundic gastric mucosal thickness was recognized in group IV as compared to group III.

The number of parietal cells is significantly increased $(P<0.001)$ in group III as compared to group I andII. Significant increase in the number of parietal cells in group IV as compared to group I and II, and non-significant difference between group VI and group III was recorded. (Table 4 and graph 4)

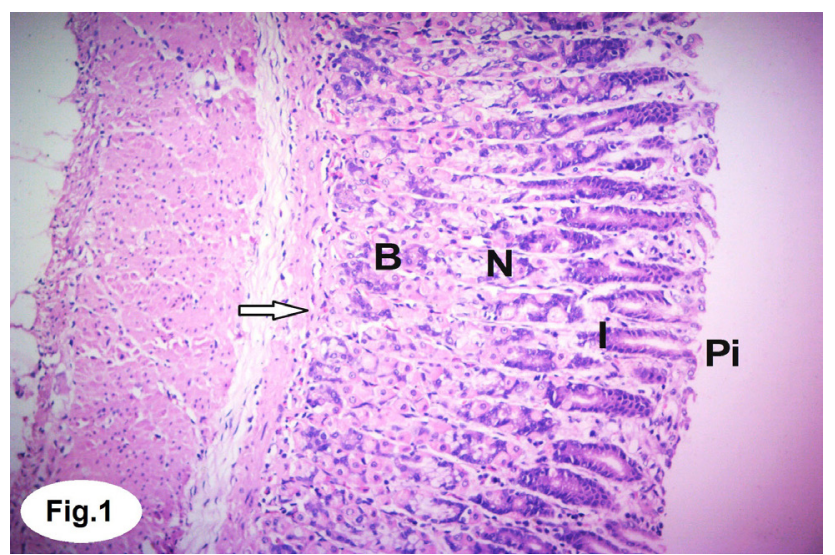

Fig. 1: A photomicrograph of a section in the fundic mucosa of the stomach of control group showing numerous, straight, tubular glands which are perpendicular to the surface. Fundic glands consist of gastric pit (Pi), ismuth (I), neck (N), and base (B). Lamina propria $(\rightarrow)$ can be seen. (Group I; H \& E x 200) 


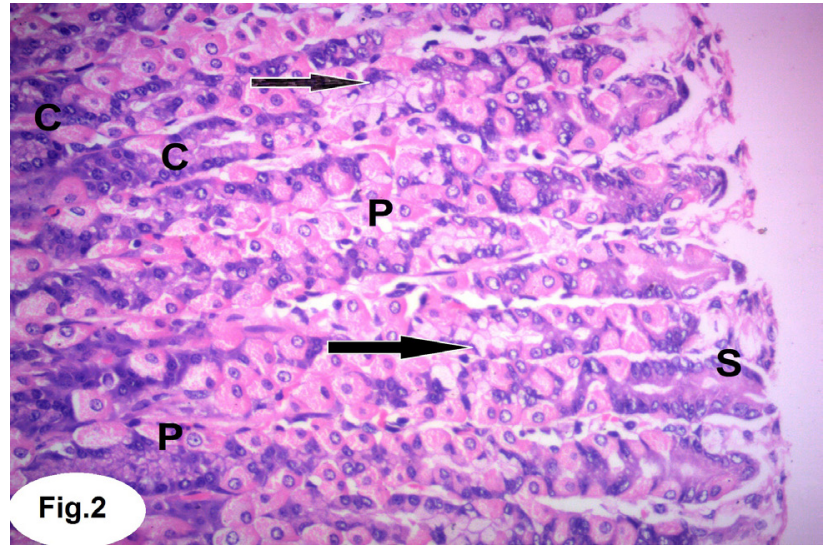

Fig. 2: A photomicrograph of a section in the fundic mucosa of the stomach of control group showing apical surface columnar epithelium (S), mucous neck cells $(\rightarrow)$ with flat basal nuclei \& pale foamy cytoplasm. Parietal cells (P) appeared large polyhedral with acidophilic cytoplasm \& central rounded nuclei and prominent nucleolus. Chief cells (C) with basal nuclei \& basophilic cytoplasm are present in the basal part of the gland giving its dark appearance. (Group I; H \&E, x 400)

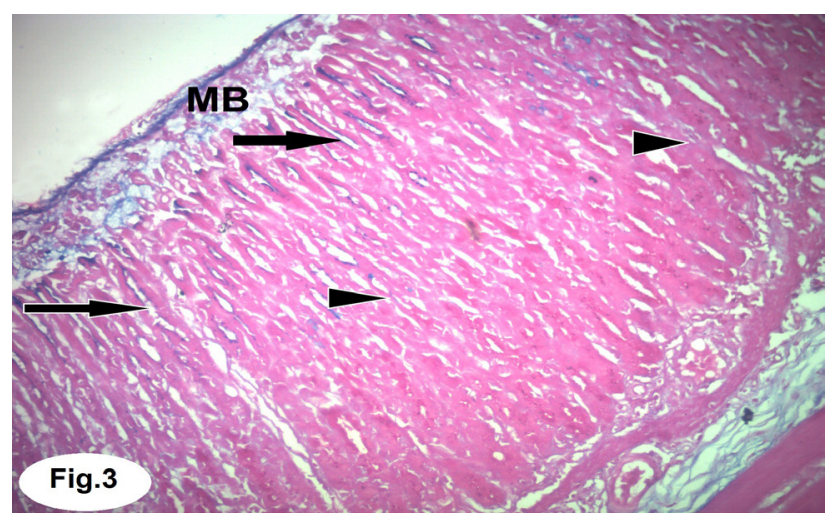

Fig. 3: A photomicrograph of a section in the fundic mucosa of the stomach of control group showing mucosal surface covered with prominent mucous barrier (MB). The apical part is showing strong positive PAS reaction. There is strong positive alcian blue reaction in the region of mucous neck cells $(\rightarrow)$ with faint reaction of gastric cells in the middle and bottom of the gland ( ). (Group I; PAS / Alcian blue, x 200)

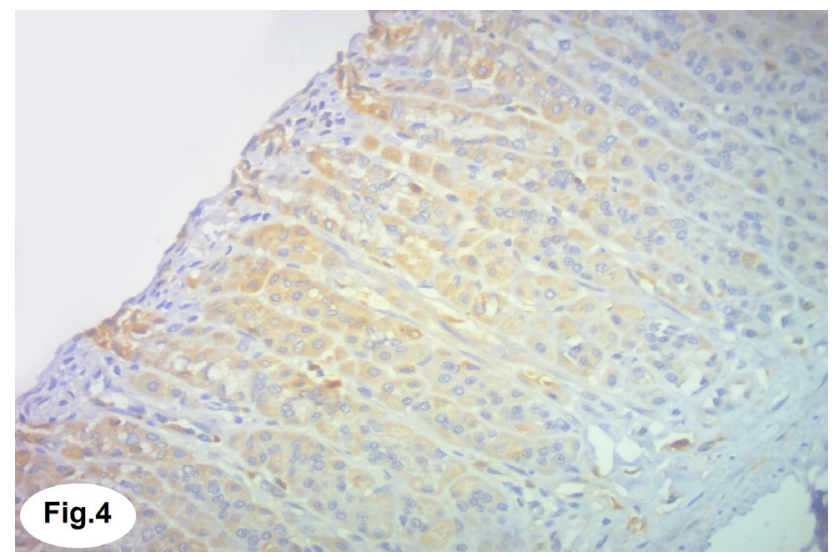

Fig. 4: A photomicrograph of a section in the fundic mucosa of the stomach of control group showing negative cytoplasmic Caspase 3 reaction in most of the fundic glands cells. (Group I; Caspase 3 immunostain, x 200)

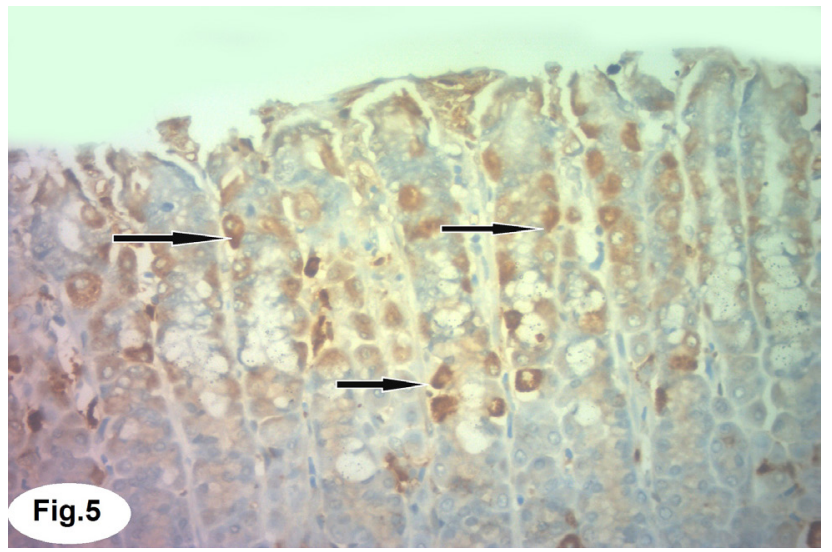

Fig. 5: A photomicrograph of a section in the fundic mucosa of the stomach of control group showing mild cytoplasmic immunoreactivity for Cox 2 in a few numbers of parietal cells $(\rightarrow)$. (Group I; Cox 2 immunostain, x 400)

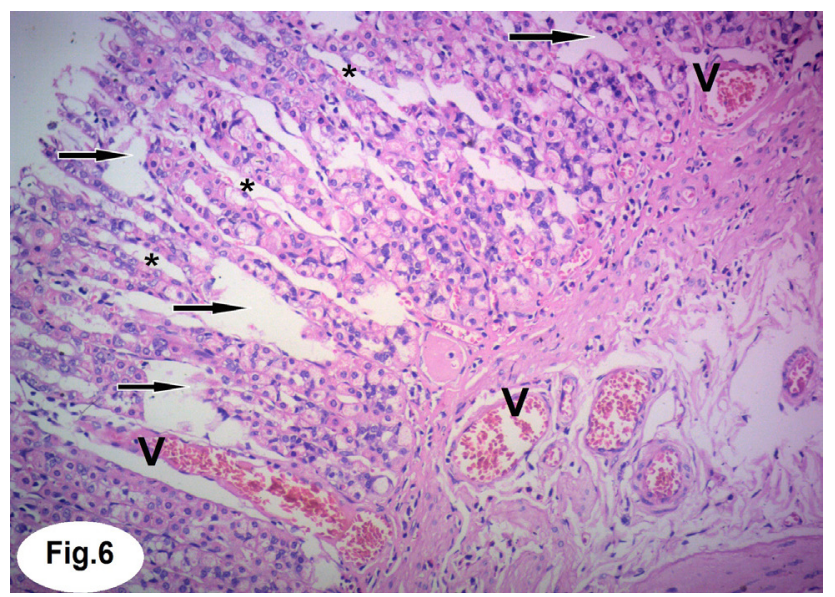

Fig. 6: A photomicrograph of a section in the fundic mucosa of the stomach of group III showing multiple areas of tissue loss $(\rightarrow)$ \& widening between the fundic gland $(*)$. Congested dilated blood vessels (V) between the glands and in the lamina propria are also seen. (Group III; H \& E, x 200)

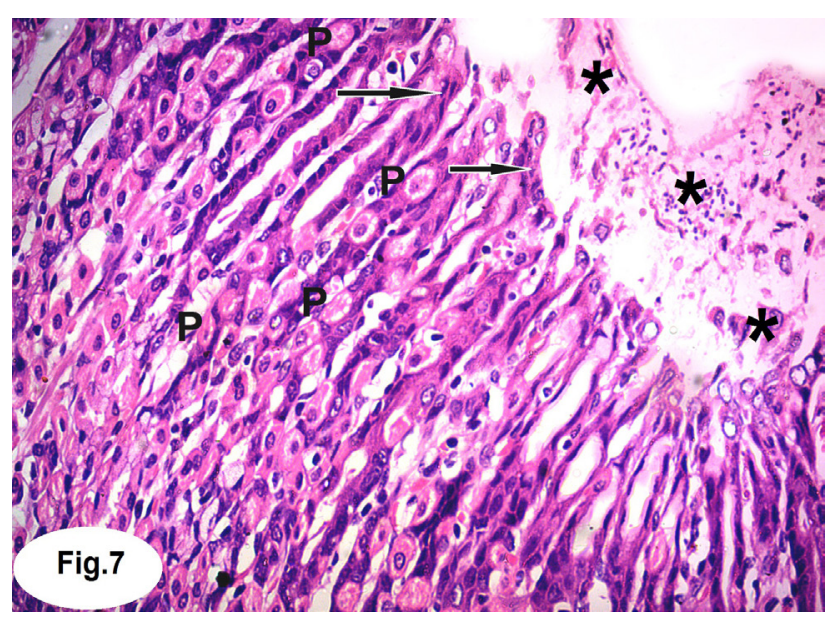

Fig. 7: A photomicrograph of a section in the fundic mucosa of the stomach of group III showing exfoliation of the superficial gastric epithelium $(*)$. Notice the surface epithelial cells with deep acidophilic cytoplasm and darkly stained flat nuclei $(\rightarrow)$. Parietal cells (P) showing vacuolated cytoplasm. (Group III; H \& E x 400) 


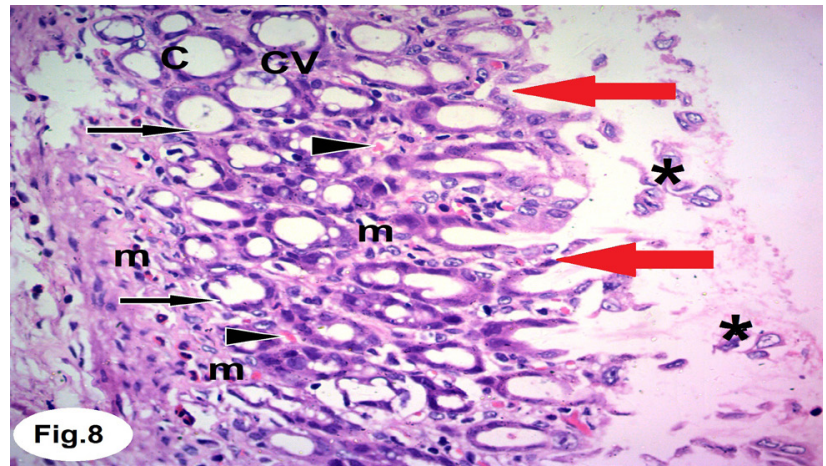

Fig. 8: A photomicrograph of a section in the fundic mucosa of the stomach of group III showing loss of superficial gastric mucosa (red arrow), exfoliation of cells $(*)$ and extravasated red blood cells between the fundic glands $(\downarrow)$. Basal part of the gland showing disorganization, dilatation \& thinning of its lining epithelium (black arrow). Some chief cells (C) appeared flat with deeply stained flattened nuclei, others showing foamy vacuolated cytoplasm (CV). Mononuclear cellular infiltration $(\mathrm{m})$ is noticed in the lamina propria and in between fundic glans. (Group III; H $\& \mathrm{E}, \mathrm{x} 400)$

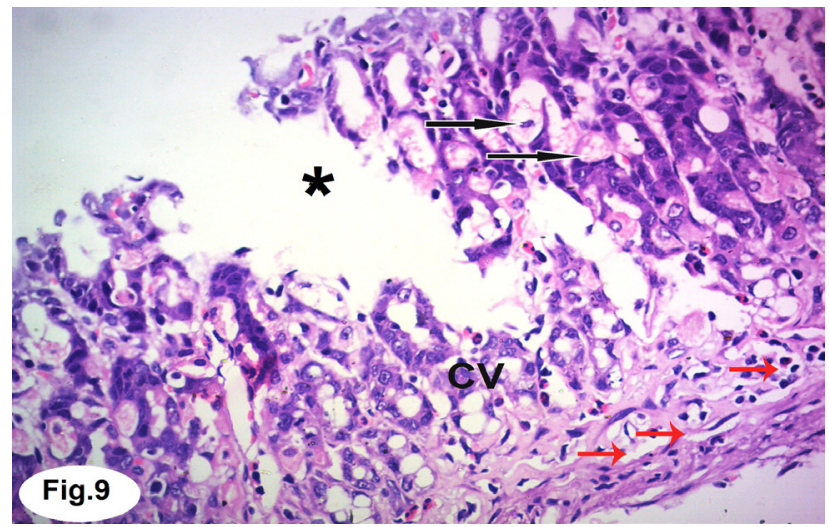

Fig. 9: A photomicrograph of a section in the fundic mucosa of the stomach of group III showing tissue loss $(*)$, ballooned vacuolated parietal cells with pykontic nuclei $(\rightarrow)$ were seen. The basal glandular part is distorted \& lined by chief cells with vacuolated basophilic cytoplasm and deeply stained flat basally located nuclei $(\mathrm{CV})$. Mononuclear cellular infiltration is also noticed (red arrow). (Group III; H\&E, x400)

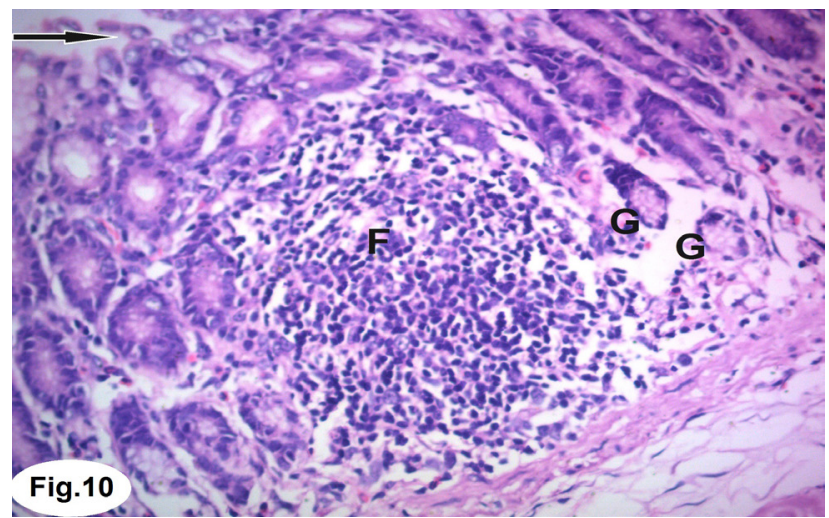

Fig. 10: A photomicrograph of a section in the fundic mucosa of the stomach of group III showing some atrophied gastric glands (G) with aggregated lymphoid cells in the form of follicle (F). Exfoliated cells are seen in the lumen $(\rightarrow$ ). (Group III; H\&E, $x$ 400)

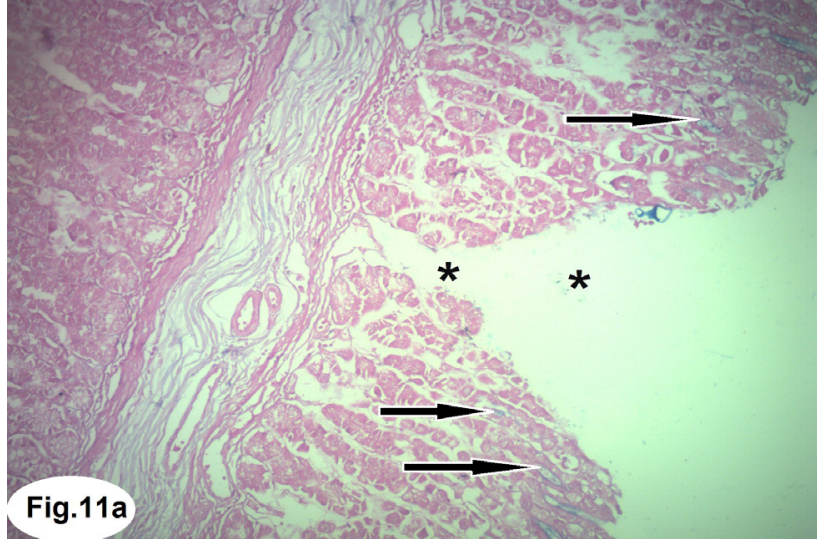

Fig. 11: A photomicrograph of a section in the fundic mucosa of the stomach of group III showing: (A) Obvious reduction in both alcian blue $(\rightarrow)$ \& PAS positive reaction can be seen. Notice the area of tissue loss $(*)$

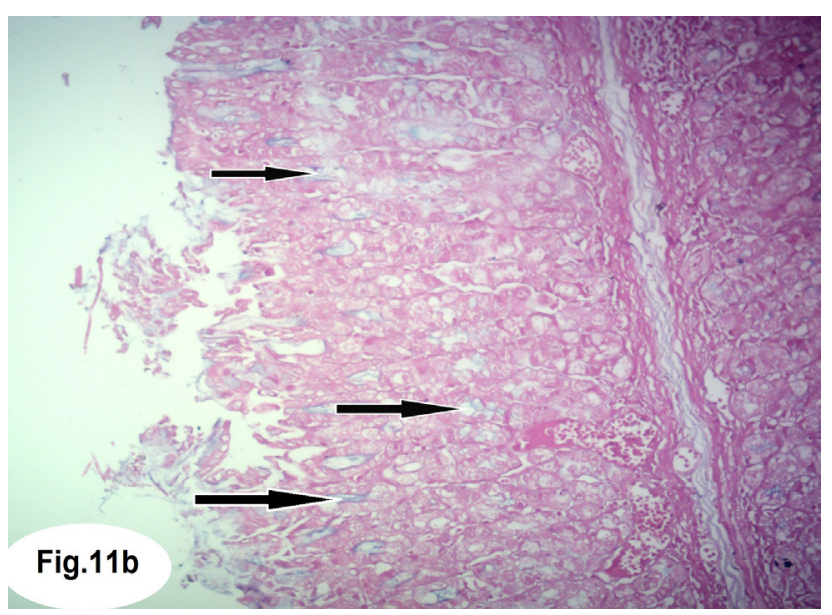

Fig. 11: A photomicrograph of a section in the fundic mucosa of the stomach of group III showing: (B) Apparent weak alcian blue positive reaction in the middle of the glands. (Group III: PAS / Alcian blue, x $200 \& 100$ )

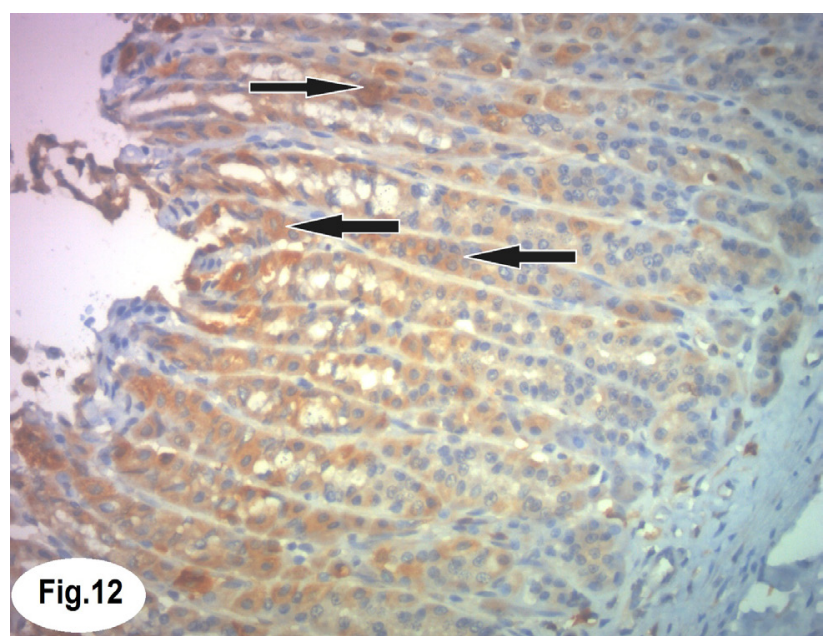

Fig. 12: A photomicrograph of a section in the fundic mucosa of the stomach of group III showing strong positive cytoplasmic Caspase 3 immune reaction in the apical \& middle parts of the gland $(\rightarrow)$, weak to moderate Caspase 3 reaction in the basal part of the gland in comparison control group. (Group III; Caspase 3 immunostain, $x$ 400) 


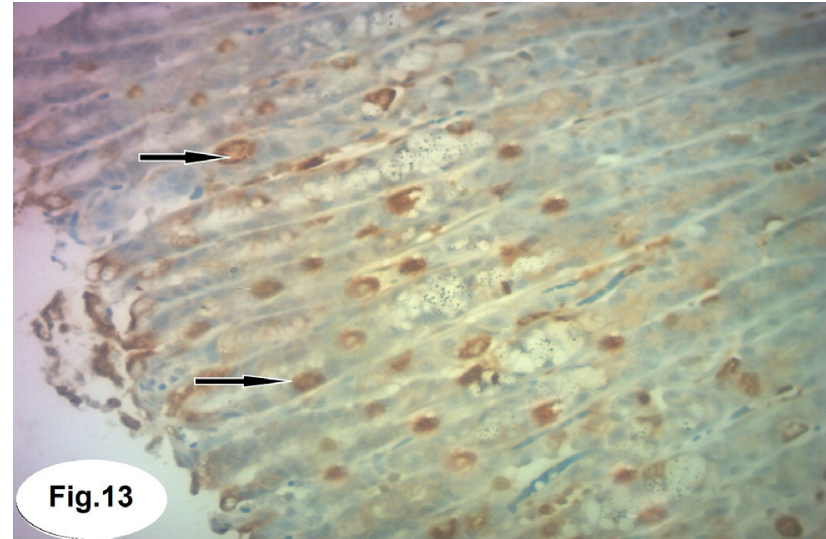

Fig. 13: A photomicrograph of a section in the fundic mucosa of the stomach of group III showing large numbers of parietal cells with positive cytoplasmic Cox 2 reaction $(\rightarrow)$ in comparison to control group. (Group III; Cox 2 immunostain, x 400)

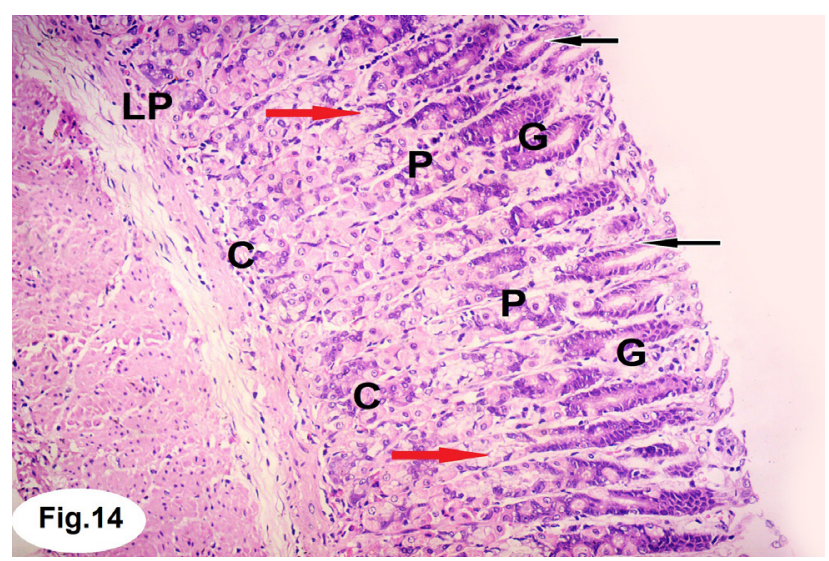

Fig. 14: A photomicrograph of a section in the fundic mucosa of the stomach of group VI showing regularly arranged fundic gland $(G)$, intact lamina propria (LP). Gastric glands are seen lined by surface columnar epithelium $(\rightarrow)$, mucous neck cells (red arrow), parietal cells $(\mathrm{P})$ \& chief cells $(\mathrm{C})$ in the basal parts. (Group VI; H \& E x 200)

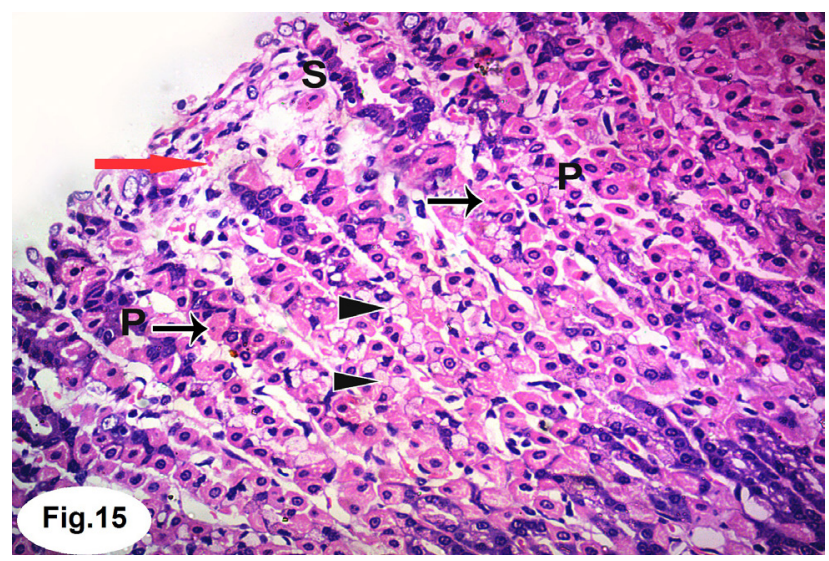

Fig. 15: A photomicrograph of a section in the fundic mucosa of the stomach of group VI showing intact mucosa lined by surface columnar cells with basal oval nuclei (S). Parietal cells (P) appeared rounded with acidophilic cytoplasm \& central vesicular nuclei; notice few parietal cells showing vacuolated cytoplasm $(\rightarrow)$. Mucous neck cells with its characteristic basal flat nuclei \& pale foamy cytoplasm are also noticed $(\boldsymbol{\nabla})$. Little extravasated blood can be seen (red arrow) (Group VI; H \&E, x 200)

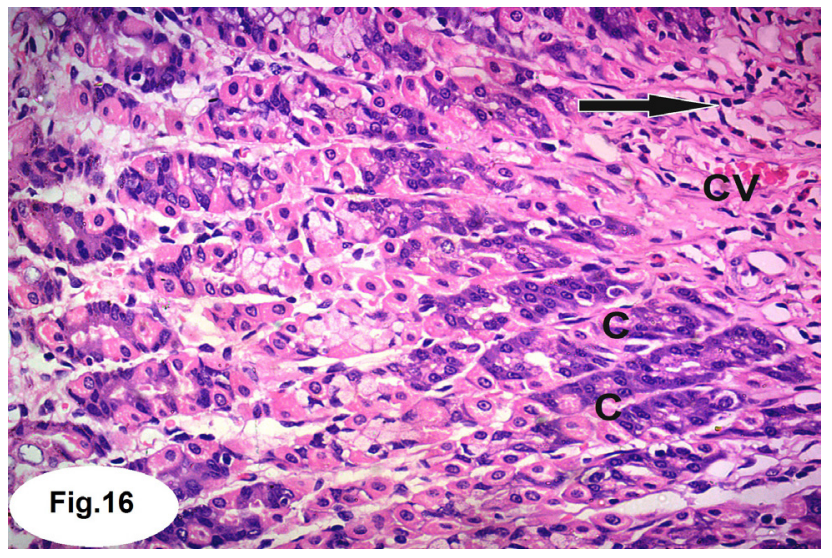

Fig. 16: A photomicrograph of a section in the fundic mucosa of the stomach of group VI showing the basal part of gastric glands lined by chief cells ( C ) with basal basophilic and apical acidophilic cytoplasm. Congested blood vessel (CV) \& few mononuclear infiltrations are seen $(\rightarrow)$ (Group VI; H \&E, x 400)

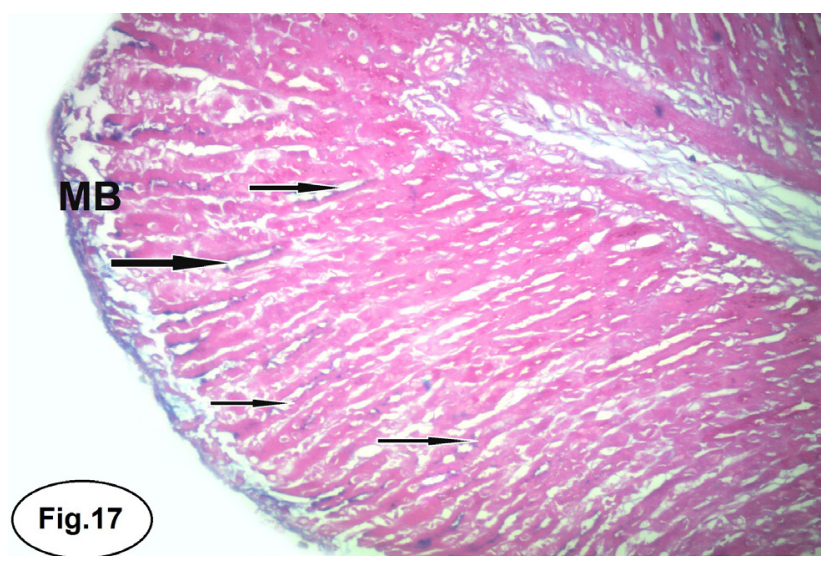

Fig. 17: A photomicrograph of a section in the fundic mucosa of the stomach of group VI showing mucosal surface covered by a continuous mucous coat (MB). The apical surface cells showing PAS positive reaction whereas the mucous neck cells showing positive alcian blue reaction $(\rightarrow)$ with faint reaction all over the rest of the mucosa. (Group VI; PAS/ Alcian blue, x 200)

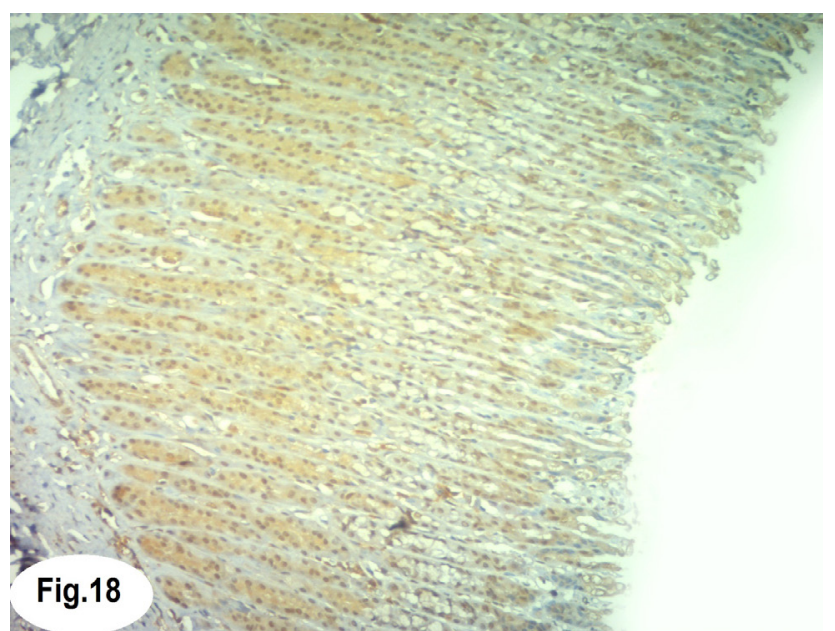

Fig. 18: A photomicrograph of a section in the fundic mucosa of the stomach of group VI showing negative cytoplasmic Caspase 3 reaction in most of gastric gland cells. (Group VI; Caspase 3 immunostain, x 200) 


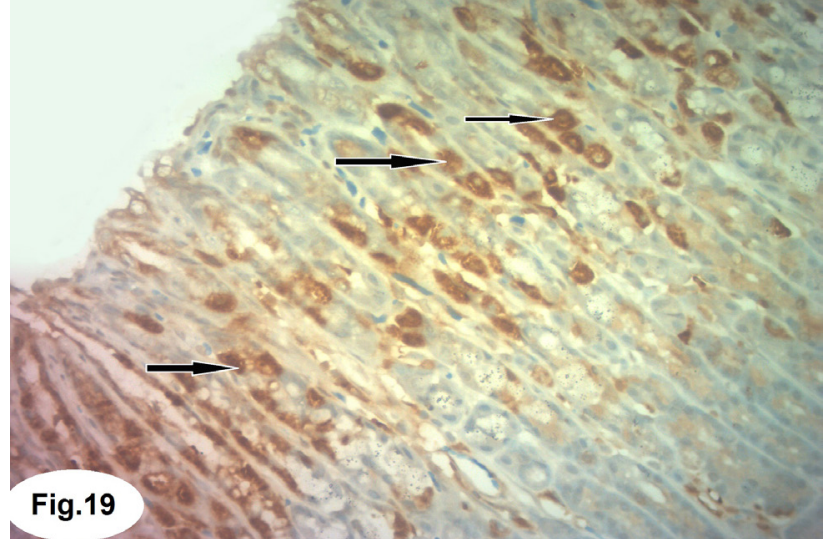

Fig. 19: A photomicrograph of a section in the fundic mucosa of the stomach of group VI showing intense cytoplasmic immunoreaction for Cox 2 large number of parietal cells $(\rightarrow)$ (Group VI; Cox 2 immunostain, x 400)

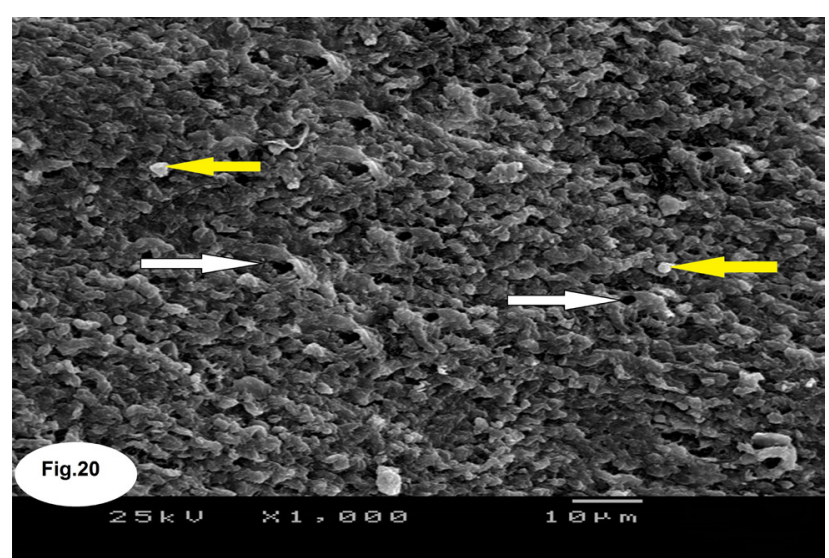

Fig. 20: Scanning electron photomicrograph of the fundus of the stomach of control (group I), showing intact surface with appearance of gastric pits (white arrow) surrounded by mucous surface cells. Notice small mucous masses scattered on the surface (yellow arrow). (Group I; SEM, x1000)

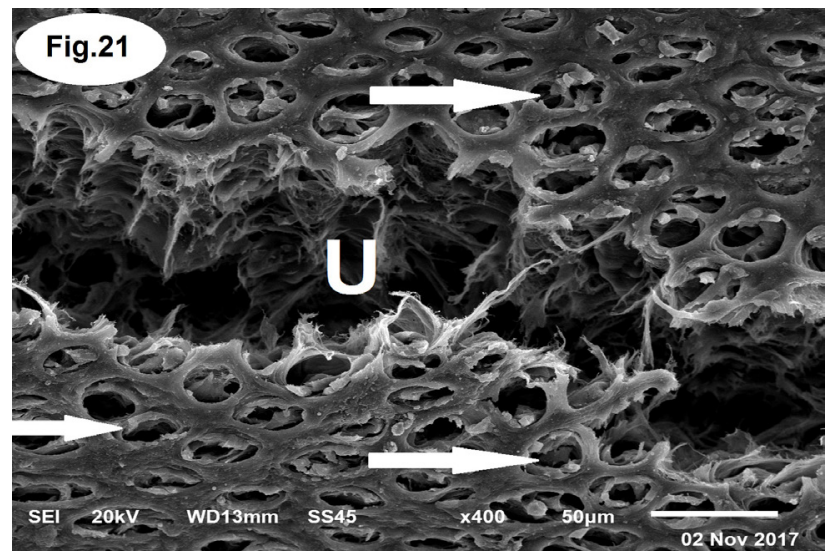

Fig. 21: Scanning electron microscopic photograph of the fundus of the stomach of (group III), showing wide ulcer in the mucosal surface extending deep in mucosal layers (U). Complete shedding of surface mucous cells leaving the walls and opening of the gastric pits with the shape of honeycomb $(\rightarrow)$. (Group III; SEM, x400)

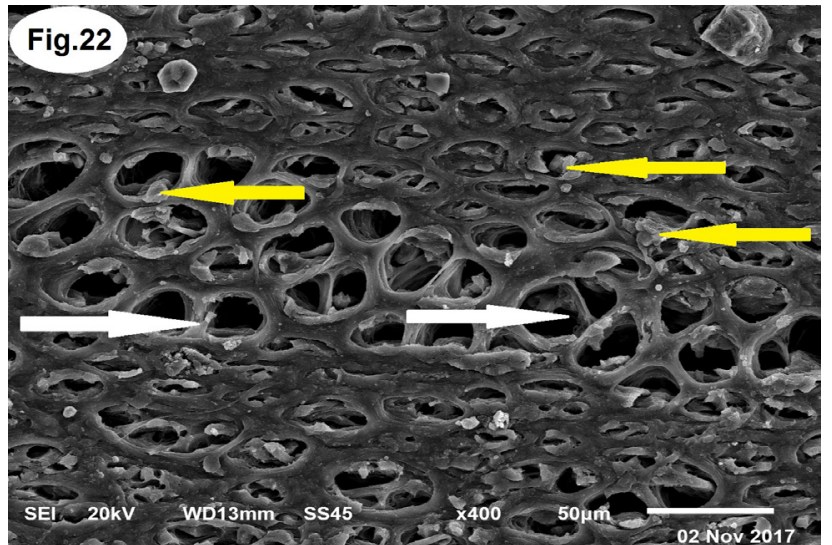

Fig. 22: Scanning electron microscopic photograph of the fundus of the stomach of (group III), showing honeycomb picture of mucosal surface (white arrow). Debris inside the dilated gastric pits is noticed (yellow arrow). (Group III; SEM, x400)

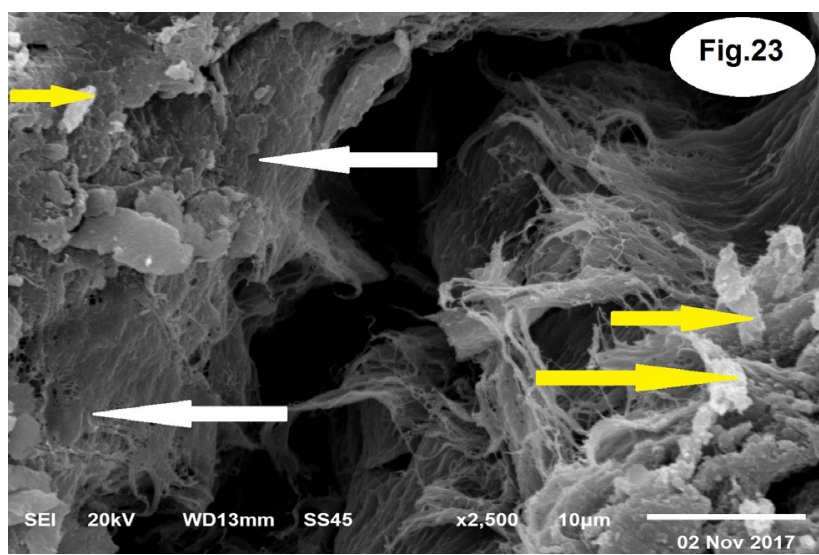

Fig. 23: Scanning electron microscopic photograph of the fundus of the stomach of (group III), showing deep mucosal ulcer reaching up to muscularis mucosa (white arrow). Debris is seen on the surface as well as deep in the ulcer (yellow arrow). (Group III; SEM, x 2500)

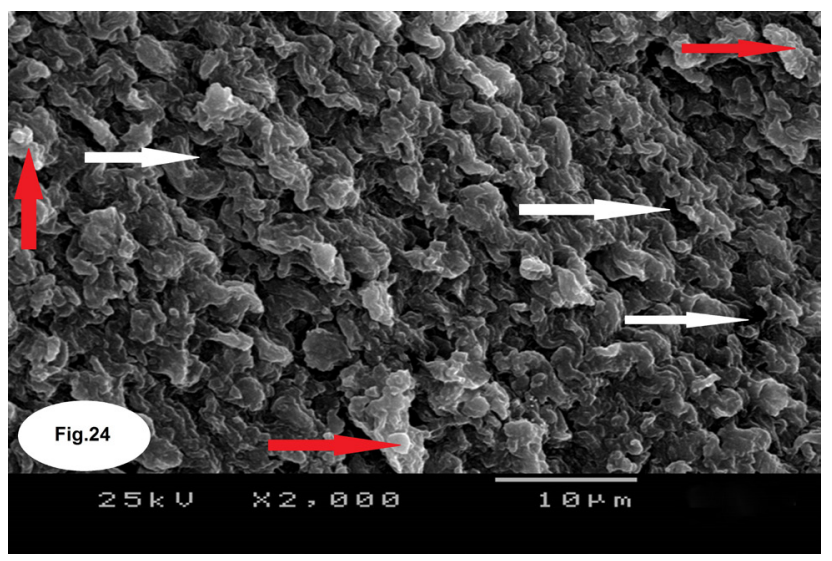

Fig. 24: Scanning electron microscopic photograph of the fundus of the stomach of (group IV), showing preserved norma architecture of gastric mucosal surface. Gastric pits (white arrow) surrounded by surface mucous cells are seen. Mucous masses are also noticed (red arrow). (Group IV; SEM, x 2500) 
Table 1: Comparison between the mean values of the final body weight of animals in the studied groups

\begin{tabular}{|c|c|c|c|c|c|c|}
\hline & Group I (control) & $\begin{array}{c}\text { Group II } \\
\text { (Ginger treated) }\end{array}$ & $\begin{array}{c}\text { Group III } \\
\text { (5 -fluorouracil treated) }\end{array}$ & $\begin{array}{c}\text { Group IV } \\
\text { (5 fluorouracil + Ginger treated) }\end{array}$ & F. test & P.value \\
\hline $\begin{array}{l}\text { Mean } \pm \text { SD of the final } \\
\text { body weight in grams }\end{array}$ & $205.2 \pm 1.64$ & $204.2 \pm 1.6$ & $170.3 \pm 0.96$ & $196.8 \pm 1.22$ & \multirow{4}{*}{26.23} & \multirow{4}{*}{0.001} \\
\hline \multirow{3}{*}{ P.value } & & $\mathrm{P} 1=0.084$ & $\mathrm{P} 2=0.001$ & $\mathrm{P} 3=0.03$ & & \\
\hline & & & $\mathrm{P} 4=0.001$ & $\mathrm{P} 5=0.045$ & & \\
\hline & & & & $\mathrm{P} 6=0.001$ & & \\
\hline
\end{tabular}

P1: Group I vs Group II $\quad$ P2: Group I vs Group III $\quad$ P3: Group I vs Group IV $\quad$ P4: Group II vs Group III $\quad$ P5: Group II vs Group IV

P6: Group III vs Group IV $\quad P$ value $>0.05=$ Non significant $\quad P$ value $<0.05=$ Significant $\quad P$ value $<0.001=$ Highly significant

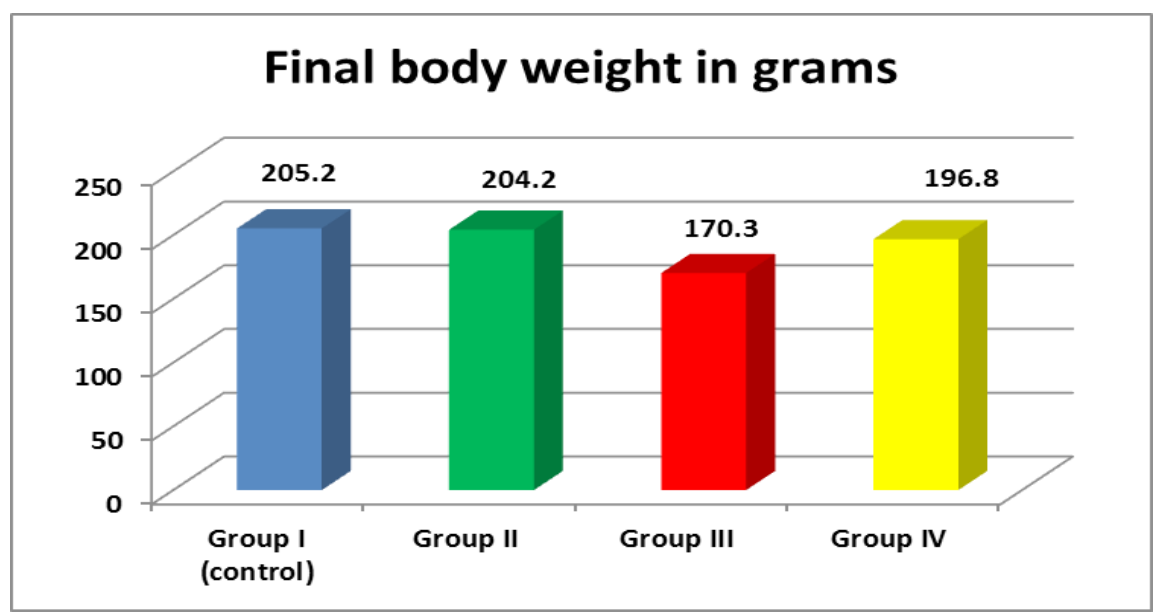

Graph 1: Mean values of the final body weight of animals in the studied groups

Table 2: comparison between the means of the fundic gastric mucosal ulcer depth in microns between the studied groups

\begin{tabular}{|c|c|c|c|c|c|c|}
\hline & Group I (control) & $\begin{array}{c}\text { Group II } \\
\text { (Ginger treated) }\end{array}$ & $\begin{array}{c}\text { Group III } \\
\text { (5 -fluorouracil treated) }\end{array}$ & $\begin{array}{c}\text { Group IV } \\
\text { (5 fluorouracil + Ginger treated) }\end{array}$ & F. test & P.value \\
\hline \multirow[t]{2}{*}{$\begin{array}{l}\text { Mean } \pm \text { SD of the } \\
\text { ulcer depth in micron }\end{array}$} & $0.525 \pm 0.171$ & $0.85 \pm 0.287$ & $128.758 \pm 1.206$ & $0.55 \pm 0.25$ & & \\
\hline & & $\mathrm{P} 1=0.254$ & $\mathrm{P} 2=0.001$ & $\mathrm{P} 3=0.924$ & 92581.421 & 0.001 \\
\hline \multirow[t]{2}{*}{ P.value } & & & $\mathrm{P} 4=0.001$ & $\mathrm{P} 5=0.256$ & & \\
\hline & & & & $\mathrm{P} 6=0.001$ & & \\
\hline
\end{tabular}

P1: Group I vs Group II $\quad$ P2: Group I vs Group III $\quad$ P3: Group I vs Group IV $\quad$ P4: Group II vs Group III P5: Group II vs Group IV P6: Group III vs Group IV $\quad P$ value $>0.05=$ Non significant $\quad P$ value $<0.05=$ Significant $\quad P$ value $<0.001=$ Highly significant

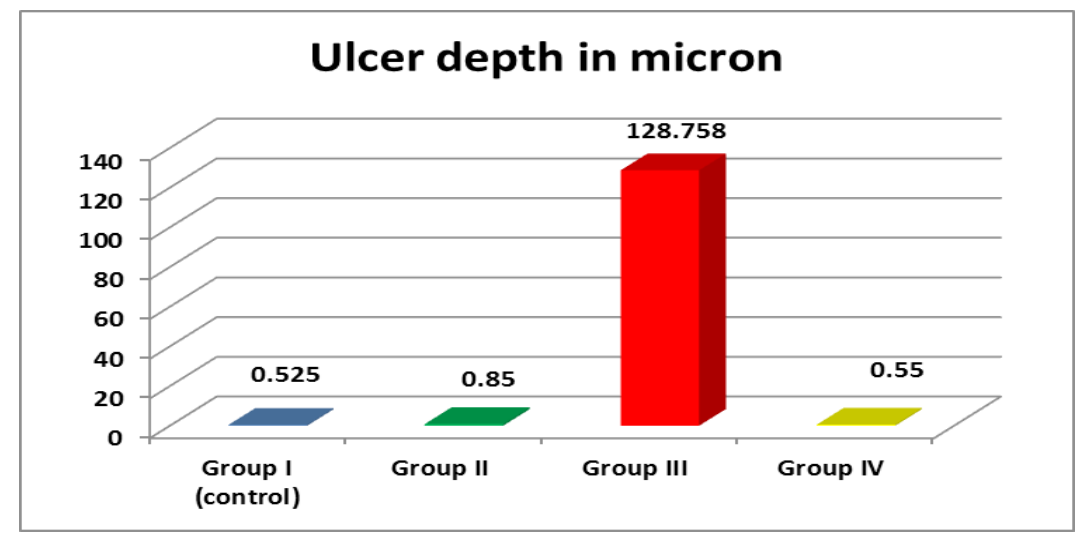

Graph 2: Mean values of fundic gastric mucosal ulcers depth in the studied groups 
Table 3: Comparison between the mean values of fundic gastric mucosal thickness in the studied groups

\begin{tabular}{|c|c|c|c|c|c|c|}
\hline & Group I (control) & $\begin{array}{c}\text { Group II } \\
\text { (Ginger treated) }\end{array}$ & $\begin{array}{c}\text { Group III } \\
\text { (5 -fluorouracil treated) }\end{array}$ & $\begin{array}{c}\text { Group IV } \\
\text { (5 fluorouracil + Ginger treated) }\end{array}$ & F. test & P.value \\
\hline $\begin{array}{l}\text { Mean } \pm \text { SD OF THE } \\
\text { mucosal thickness } \\
\text { in micron }\end{array}$ & $248.2 \pm 3.4$ & $235.6 \pm 34.9$ & $184.95 \pm 1.057$ & $224.9 \pm 2.9$ & & \\
\hline \multirow{3}{*}{ P.value } & & $\mathrm{P} 1=0.087$ & $\mathrm{P} 2=0.001$ & $\mathrm{P} 3=0.002$ & 10275.392 & 0.001 \\
\hline & & & $\mathrm{P} 4=0.001$ & $\mathrm{P} 5=0.145$ & & \\
\hline & & & & $\mathrm{P} 6=0.001$ & & \\
\hline
\end{tabular}

P1: Group I vs Group II P2: Group I vs Group III $\quad$ P3: Group I vs Group IV $\quad$ P4: Group II vs Group III $\quad$ P5: Group II vs Group IV P6: Group III vs Group IV $\quad P$ value $>0.05=$ Non significant $\quad P$ value $<0.05=$ Significant $\quad P$ value $<0.001=$ Highly significant

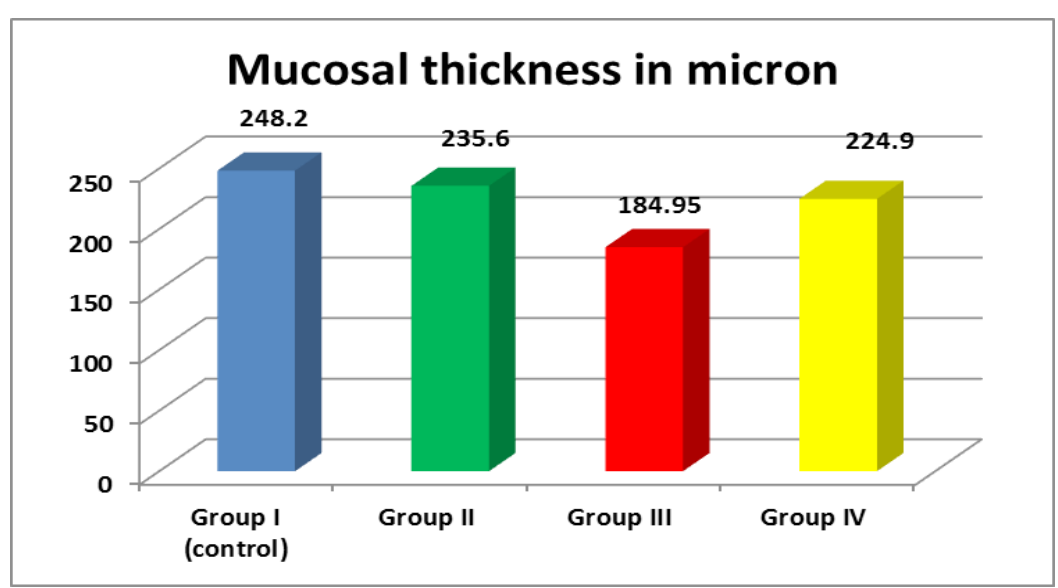

Graph 3: Mean values of fundic gastric mucosal thickness in the studied groups

Table 4: Comparison between the mean values of number of parietal cells in fundic gastric mucosa in the studied groups

\begin{tabular}{|c|c|c|c|c|c|c|}
\hline & Group I (control) & $\begin{array}{c}\text { Group II } \\
\text { (Ginger treated) }\end{array}$ & $\begin{array}{c}\text { Group III } \\
\text { (5 -fluorouracil treated) }\end{array}$ & $\begin{array}{c}\text { Group IV } \\
\text { (5 fluorouracil + Ginger treated) }\end{array}$ & F. test & P.value \\
\hline $\begin{array}{l}\text { Mean } \pm \text { SD of the } \\
\text { number of parietal cells }\end{array}$ & $60.125 \pm 1.218$ & $58.45 \pm 0.79$ & $65.2 \pm 3.04$ & $66.91 \pm 1.3$ & \multirow{4}{*}{4337.644} & \multirow{4}{*}{0.001} \\
\hline \multirow{3}{*}{ P.value } & & \multirow[t]{3}{*}{$\mathrm{P} 1=0.056$} & $\mathrm{P} 2=0.001$ & $\mathrm{P} 3=0.001$ & & \\
\hline & & & $\mathrm{P} 4=0.041$ & $\mathrm{P} 5=0.001$ & & \\
\hline & & & & $P 6=0.52$ & & \\
\hline
\end{tabular}

P1: Group I vs Group II $\quad$ P2: Group I vs Group III $\quad$ P3: Group I vs Group IV $\quad$ P4: Group II vs Group III P5: Group II vs Group IV P6: Group III vs Group IV $\quad P$ value $>0.05=$ Non significant $\quad P$ value $<0.05=$ Significant $\quad P$ value $<0.001=$ Highly significant

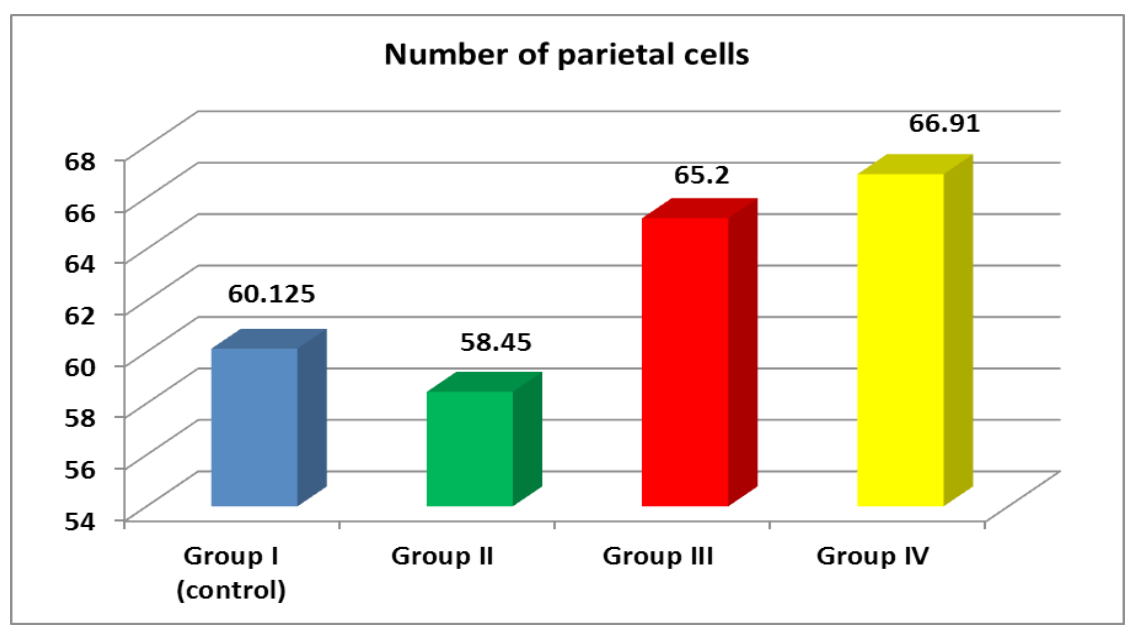

Graph 4: Mean values of parietal cells number in fundic gastric mucosa in the studied groups 


\section{DISCUSSION}

Intake of chemotherapy in different types of cancer is accompanied with many adverse effects mainly in gastrointestinal tract which result in morbidity associated with chemotherapy treatment ${ }^{[21]}$. The gastric epithelium has rapid turnover with more vulnerability to chemotherapy ${ }^{[22]}$. 5-fluorouracil is a chemotherapeutic anti-metabolite agent used as anticancer therapy with subsequent gastric and intestinal injury in the form of mucositis and ulcers ${ }^{[23,24]}$.

All these findings suggest the need for use of herbal therapy to ameliorate the 5-fluorouracil effect, hence the use of ginger in the present study. In previous studies, the effect of ginger on peptic ulcer was demonstrated in animal models $^{[13,8]}$. Moreover, the mechanism of protective role of ginger in gastric injury is still unclear. Hence, the aim of the current study was to study the ameliorative effect of ginger in 5-fluorouracil induced gastric injury in rat model.

In the present study, there was a significant reduction of rat weight in 5 fluorouracil treated group when compared to control group. The previous data was in accordance with the work of some scientists, who reported weight reduction in both foetuses of pregnant female rats as well as in pregnant rats after their administration of 5- fluorouracil ${ }^{[25]}$. They stated that, weight reduction was dose related as increase weight loss with increase uptake dose of chemotherapy. This may be attributed to decreased digestive function due to direct toxic effect of 5-flurouracil in gastrointestinal mucosa as well as multiple organ toxicity.

Microscopic examination of 5 fluorouracil treated group showed dilated congested blood vessels and extravasated red blood cells between fundic gland cells and lamina propria. These findings were in line with the study of group of scientists that showed extravasated red blood cells in the gastric lamina propria after 5-FU administration in mice ${ }^{[23]}$. Some scientists explained the enhanced gastric blood flow due to disturbance in gastric microcirculation ${ }^{[26]}$. Moreover, other authors demonstrated decline in gastric mucosal blood flow and increased submucosal and serosal flow ${ }^{[27]}$.

In the current study, variable degrees of fundic mucosal lesion, multiple areas of tissue loss with exfoliation of epithelium. These findings were in agreement with findings reported by some authors, who studied the adverse effect of repeated administration of 5-FU therapy in rat stomach that caused the morphological and functional derangement of the stomach and increased the mucosal vulnerability against $\operatorname{acid}^{[28]}$. Other experimental work correlates gastric ulcer to disturbance and defect in regulation of gastric microcirculation with subsequent mucosal surface hypoxia $^{[29]}$. Cellular hypoxia results in intracellular and extracellular release of lysosomal enzymes which induce their damage and enhance fragility of surface epithelium. While, another study correlates ulcer formation to suppression of cyclo-oxygenase production with resulting inhibition of mucus secretion which impair important gastrointestinal defensive mechanism ${ }^{[30]}$. The mechanism of gastric ulcer and mucosal injury induced by 5-FU may be attributed due to nuclear factor [NF-kB] activation with resulting accumulation of active proteins in the sub mucosal tissue in gastrointestinal tract which elicit inflammatory and apoptotic response with subsequent increase in expression proinflammatory cytokines as interleukin 1 and 6 leading to mucosal injury and ulcer formation ${ }^{[31]}$.

Moreover, ulcer findings were confirmed by morphometric measurements which showed highly significantly increased in fundic gastric mucosal ulcer depth and a significant reduction in gastric mucosal thickness in 5-FU treated group when compared to control group. These findings were in agreement with the work of some scientists, who reported reduction in the thickness of duodenal mucosa and villi height ${ }^{[32]}$.

In the present study, the results revealed that, PAS/ Alcian blue stained sections of fundic gastric gland after 5- FU administration showed PAS/Alcian blue positive reactions in the basal cells of the fundic gland and deficient mucus layer in surface of gastric gland. Some scientists explained this reaction due to defect in differentiation of chief cell lineage to mucous cells ${ }^{[33]}$. Another experimental work attributed defective mucus biosynthesis due to impaired gastric defensive factor because of suppression of prostaglandin biosynthesis ${ }^{[34]}$. In group IV after ginger administration, the fundic mucosa of the stomach showed mucosal surface covered by a continuous mucous coat which stained positive with PAS /Alcian blue stain. The Scanning electron microscopic photos proved this result denoted by presence of mucus masses overlying the gastric surface pointing to increased mucus secretion. This finding was in line with the results of a study done by group of scientists, who explained increased mucus biosynthesis due to cytoprotective effect of ginger as well as endogenous secretion of prostaglandin ${ }^{[35]}$.

Mononuclear cellular infiltrate reported in the lamina propria and extending to the basal part of the fundic gland in 5-Fu treated group can be resorted to interaction between mononuclear-endothelial cells as a result of gastric injury ${ }^{[36]}$.

The results of the current study revealed different appearance of chief cells. Some cells were flattened with flattened nuclei, others with foamy cytoplasm. While the parietal cells showed ballooned vacuolated cytoplasm with dark pyknotic nuclei. These results were in line with findings revealed by some authors, who reported same effect after 5-FU injection. Such pathological changes may be attributed to the toxic adverse effects of the chemotherapy on the gastric cells ${ }^{[23]}$. Degeneration and apoptosis of cells on the basal part of fundic gland as well as parietal cells was expressed as positive immunoreactivity to caspase 3 in the parietal cells cytoplasm and cells present in the glandular base as shown in the current study. Caspases represent main constituent of mammalian cells apoptotic cascade. It is a prominent mechanism for disposal of unwanted and defective cells ${ }^{[37]}$. One of the main members of caspase family is Caspase 3 which sensitized as a result of tissue 
apoptosis with endonuclease activation and a sequalae of DNA fragmentation ${ }^{[38]}$.

COX is the rate-limiting enzyme in the cascade of synthesis of prostaglandin from its progenitor arachidonic $\operatorname{acid}^{[39]}$. There are two forms of COX; COX1 and COX2. COX2 is stimulated in epithelial cells of stomach in case of in vitro growth stimulation and in vivo after damage induced by acid ${ }^{[39,40]}$. The study done by a group of scientists reported that the position and the morphology of the Cox 2 immunopositive cells in the gastric glands suggested that these were parietal cells ${ }^{[41]}$, they also confirmed their suggestion by electron microscopic study that demonstrated Cox2 in parietal cell's smooth endoplasmic reticulum. These findings goes with the results of the current study as there was strong cytoplasmic immunopositivty for Cox2 at the site of parietal cells in the gastric glands treated with 5- fluorouracil. A significant increase in the number of parietal cells with Cox 2 positive reaction in comparison to control can be explained by the work of some scientists, who reported high levels of Cox $2 \mathrm{~m}$ RNA during the acute stages of gastric erosion and ulcers and combined that to Cox 2 role in the repair process of these lesions ${ }^{[42]}$. This also explains the high significant increase in the number of parietal cells in group VI when compared to control group.

Using scanning electron microscopic examination of 5-FU-treated rats showed loss of gastric mucosa leading to irregular variable openings in the gastric pits leading to honey comb appearance. The previous findings were correlated with the work carried out some authors who reported absent demarcation between gastric mucus cells associated with multiple area of necrosis and umbilicated depressed apices ${ }^{[23]}$. Other areas showed ulcers and complete shedding of mucosa.

In the present study, examination of the rat gastric fundus of group IV which received ginger with 5-FU reported near normal fundic mucosal gland with still minimal flattened parietal cells, mild extravasated and congested blood vessels with smaller area of mononuclear infiltration. This improvement of pathological changes can be explained by ginger administration due to alleviation of the apoptotic and inflammatory effect in gastric fundus and conserve against gastric toxicity. There was a study that demonstrated that, ginger intake protects against aspirin induced gastric ulcer in rat ${ }^{[13]}$. The research of some scientists explained gastroprotective effect of ginger due to inhibition of inducible form of nitric oxide synthase [iNOS] activity ${ }^{[43]}$. Another study, explained this protection as a result of decrease the TNF- and IL-1 expression in gastric cells and subsequent inhibition gastric ulcers development ${ }^{[44]}$.

The main compositions of ginger powder are 10-gingerol, 8-gingerol, 6-shogaol and 6-gingerol ${ }^{[45]}$. Administration of ginger exhibited improvement of antiinflammatory property and preventing the injury to gastric tissue. The experiments of some scientists revealed that ginger oil administration has antisecretory effect as it block the diffusion of hydrogen ions, and noted by the reduction in total acidity as well as decreased volume of gastric juice ${ }^{[8]}$. Moreover, the ginger oil intake displayed cytoprotecting effect because of increasing gastric mucus wall thickness and reduction of serum $\gamma$-GTP levels.

Administration of ginger stimulate the antioxidant properties and suppress gastric injury as ginger is a strong antioxidant plant which protects the rat blood from the side effects of exposure to cadmium chloride and cadmium chloride-induced oxidative stress $^{[46]}$. Some scientists noticed that, Zingberaceae officinale, can decrease oedema, and lipid peroxidation and increased the enzyme, Super Oxide Dismutase (SOD) activity ${ }^{[47]}$.

Thus, in the current work, ginger may ameliorate the pathological effect of administration of 5-FU chemotherapy through its anti-inflammatory and anti-oxidant properties.

\section{CONCLUSION}

5-FU causes gastric damage in rat model. Ginger supplementation could be used to alleviate the damaging pathological effect on gastric fundus. It can be supplemented in diet for prevention of gastric injury and gastric disease.

\section{CONFLICTS OF INTEREST}

There are no conflicts of interest

\section{REFERENCES}

1. EL Hak, H; Moawad, T. and Hafez, G. (2015): Histological Study of the Effect of Chemotherapy with 5-Fluorouracil on Normal Liver and Kidney of Mice . International Journal of Novel Research in Life Sciences Vol. 2, Issue 1: 8-13.

2. Colovic, M. ; Bogdanovic, A.; Jankovic, G.; Kragul, N. And N. Suvajdzic (2003) : Long-term survival in acute lymphoblastic leukemia in adults treated according to the LALA87 protocol. Chemotherapy; 49: 138-145.

3. Sobrero, A.; Aschele. C. and Bertino, J. (2000): Fluorouracil in colorectal cancer--a tale of two drugs: implications for biochemical modulation. J Clin Oncol; 15: 368-81

4. Lemaire, L.; MaletMartino, M.; Forni, D.; Martino, R and Lasserre, B. (2000): Cardiotoxicity of commercial 5-fluorouracil vials stems from the alkaline hydrolysis of this drug. Br J Cancer ; 66: 119-27.

5. Al-Hamdany, M. and Al-Hubaity, A. (2014): The structural changes of the rat's lung induced by intraperitoneal injection of 5-fluorouracil. J Pak Med Assoc. Vol. 64, No. 7 : 734-738.

6. El-Sayyad, H. ; Ismail, M. ; Shalaby, F.; Abou-El-Magd, R.; Gaur, R. and Fernando, A (2009): Histopathological effects of Cisplatin, Doxorubicin and 5-Fluorouracil (5-FU) on the liver of male albino rats. Int J Biol Science; 5: 466-73. albino rat. The Egyptian Journal of Histology. Vol. 38 - Issue 3 - p 415-426. 
7. Yazbeck, R; Lindsay, R.; Abbott, C; Benkendorff, K.; and Howarth, G (2015): Combined Effects of Muricid Extract and 5-Fluorouracil on Intestinal Toxicity in Rats. Evidence-Based Complementary and Alternative Medicine. Vol 2015; 1-9. Hindawi Publishing Corporation.

8. Khushtar, M.; Kumar, V.; Javed, K. and Bhandari, U. (2009): Protective effect of ginger oil on aspirin and pylorus ligation induced gastric ulcer model in rats. Ind J of Pharmaceutical Sciences; 71:554-558.

9. Zaman, S; Mirje, M. and Ramabhimaiah, S (2014): Evaluation of the anti-ulcerogenic effect of Zingiber officinale (Ginger) root in rats . Int.J.Curr. Microbiol. App. Sci ; 3(1): 347-354

10. Sindi, H. and Basaprain, R. (2016): Protective effect of ginger and cinnamon aqueous extracts against aspirin-induced peptic ulcer.World Applied Sciences. J.;34(11): 1436-1448

11. Ghayur, M and Gilani, H. (2005): Pharmacological basis for the medicinal use of ginger in gastrointestinal disorders. Dig Dis Sci. ;50:1889-97.

12. Shukla, Y. and Singh, M. (2007): Cancer preventive properties of ginger: A brief review. Food Chem Toxicol.; 45:683-90.

13. Wang, Z; Hasegawa, J ; Wang, X; Matsuda, A; Tokuda, T; Miura, N. and Watanabe, T. (2011): Protective Effects of Ginger against Aspirin-Induced Gastric Ulcers in Rats. Yonago Acta medica. 54:11-19.

14. Stevens, A. and Wilson, G. (1996): The haematoxylin and eosin. In: Bancroft, J, Stevens, A and Turner, D: (Theory and practice of histological techniques. $4^{\text {th }}$ edition: Churchill Livingstone, New York

15. Piazuelo, M; Haque, S; Delgado1, A; Du, J; Rodriguez, F. and Correa, P. (2004): Phenotypic differences between esophageal and gastric intestinal metaplasia. Modern Pathology. 17; 62-74

16. Lee, j.; Jeng, S. and Lee, T. (2006): Increased activated caspase- 3 expression in testicular germ cells of varicocele-induced rats. JTUA. 17(3):8185

17. Maneen, B. and Yamauchi, K. (2003): Effects of semipurified pellet diet on the chicken intestinal villus histology. Poult. Sci, 40:254-266.

18. Hassan, S. and Moussa. E. (2015): Light and scanning electron microscopy of the small intestine of goat (Capra hircus). Journal of cell and animal biology. Vol.9 (1).pp. 1-8. January.

19. De Conto, C.; Oevermann, A.; Burgener I.; Doherr, M. and Blum J. (2010). Gastrointestinal tract mucosal histomorphometry and epithelial cell proliferation and apoptosis in neonatal and adult dogs. J Anim Sci., 88 (7):1-26.
20. Peat J and Barton B. (2005): Medical Statistics. A Guide to data analysis and critical appraisal. First Edition. Wiley-Blackwell.

21. Gawish, S.; Nosseeir, D.; Omar, N. and Sarhan, N. (2013): Histological and ultrastructural study of 5-fluorouracil-induced small intestinal mucosal damage in rats. Asian J. of Cell Biology. 8 (1); 1-21.

22. Yanez, J.; Teng, X.; Fanss, M. and Davies, N. (2003): Chemotherapy induced gastrointestinal toxicity in rats: Involvement of mitochondrial DNA, gastrointestinal permeability and cyclooxygenase-2. J.Pharm. Sci., 6:308-314.

23. El-Bermawy, M. (2015): Light and scanning electron microscopic study of 5-fluorouracil-induced mucosal injury in the gastric fundus and the possible protective role of omeprazole in adult male albino rat. The Egyptian Journal of Histology. Vol. 38 - Issue 3 - p 415-426.

24. Soares, P.; Lima-Junior, R.; Mota, J. and Brito, G. (2011): Role of platelet-activating factor in pathogenesis of 5-fluorouracil-induced intestinal mucositis in mice. Cancer Chemotherapy. Pharmacol., 68:713-720.

25. Yamaguchi, Y.; Aoki, A.; Fukunaga, Y.; Matsushima, K.; Ebata,T.; Ikeya, M. and Tamura, K. (2009): 5-Fluorouracil-induced histopathological changes in the central nervous system of rat fetuses. Histol Histopathol ; 24: 133-139

26. Ohta, M.; Hashizume, M.; Higashi, H.; Ueno, K. and Tomikawa, M. (1994): Portal and gastric mucosal hemodynamics in cirrhotic patients with portal hypertensive gastropathy. Hepatology; 20: 1432-36.

27. Gupta, R.; Sawant, P.; Parameshwar, R.; Lele, V.; Kulhalli, P. and Mahajani, S. (1998): Gastric mucosal blood flow and hepatic perfusion index in patients with portal hypertensive gastropathy. J.Gastroenterol. Hepatol.; 13: 921-26

28. Kotani, T.; Nakagiri, A. and Murashima, Y. (2007): Prophylactic effect of lafutidine against the adverse reaction induced in rat stomach by repeated administration of 5-fluorouracil. Inflammo-pharmacology J. 15: 259-270.

29. Abd El-Haleem, M.; Soliman, H. and Abd ElMotteleb, D. (2013): Effect of experimentally induced portal hypertension on the fundic mucosa of adult male albino rats and the possible protective role of quercetin supplementation: histological, immune-histochemical and biochemical study. Egypt. J. of Histol.; 36:60-77

30. Ozbaklfi-Dengzi, G.; Cadircl, E. and Yurdakan, G. (2011): Histopathologic evaluation of anti-ulcerogenic effect of montelukast in indomethacin-induced experimental ulcer model. Turk J Gastroenterol ; 24 (2): 88-92. 
31. Chang, C.; Ho, T.; Liang, H.; Huang, H.; Li, C.; Lo, H.; Wu, S.; Hauang, Y. and Hsiang, C. (2012): 5-fluorouracil induced intestinal mucositis via nuclear factor $-\mathrm{kB}$ activation by transcriptomic analysis and invivo bioluminescence imaging.Plos One. Vol.7.(3).e31808.1-8.

32. Olaibi, O.; Ijomone, O. and Ajibade. A. (2014): Histomorphometric study of stomach and duodenum of aspirin treated Wistar rats. Journal of Experimental and Clinical Anatomy. Vol. 13. Issue 1; 12-16.

33. Goldenring, J.; Nam, K. and Mills, J. (2011): The origin of pre-neoplastic metaplasia in the stomach: chief cells emerge from the Mist. Exp. Cell Res.; 317: 2759- 64

34. Bandyopadhyay, S.; Pakrashi, S. and Pakrashi, A. (2000): The role of antioxidant activity of Phyllanthus emblica fruits on prevention from indomethacin induced gastric ulcer. J Ethno-pharmacol; 70: 171-6.

35. Al Mofleh I, Alhaider A, Mossa J, Al-Sohaibani M, Al-Yahya M, Rafatullah $\mathrm{S}$ and Shaik S. (2008): Gastroprotective effect of an aqueous suspension of black cumin Nigella sativa on necrotizing agents-induced gastric injury in experimental animals. Saudi J. Gastroenterol.; 14(3):128-134.

36. Zaki, S. and Mohamed, E. (2014): Effect of glucocorticoids on indomethacin-induced gastric ulcer in the adult male albino rat - histological, morphometric and electron microscopy study. Arch Med Sci; 10, 2: 381-388

37. Said, T.; Paasch, U.; Glander, H. and Agarwal, A. (2004): Role of caspases in male infertility. Hum. Reprod. Update.; 10: 39-51.

38. Turner, T. and Lysiak, J. (2008): Oxidative stress: a common factor in testicular dysfunction. J. Androl.; 29:488-89

39. Sun, W.; Tsuji, S.; Tsujll, M.; Gunawan, E.; Kawai, N.; Kimura, A.; Kakiuchi, Y.; Yasmaru, M.; Iijima, H.; Okuda, Y.; Sasaki, Y.; Hori, M. and and Kawano, S. (2000): Induction of Cyclooxygenase-2 in rat gastric mucosa by rebamipide, a mucoprotective agent. J. of Pharmacology and Experimental therapeutics. Vol. 295:447-452.

40. Sawaoka, H.; Tsuji, S.; Tsujii, M.; Gunawan, E.; Nakama, A.; Takei, Y.; Nagano, K.; Matsui, H.; Kawano, S. and Hori, M. (1997): Expression of the cyclooxygenase-2 gene in gastric epithelium. J Clin Gastroenterol 25 (Suppl 1):S105-S110

41. Jackson,L.; Wu,K.; Mahida,Y.; Jenkins,D. and Hawkey,C. (2000): Cyclooxygenase(Cox) 1 and 2 in normal, inflamed, and ulcerated human gastric mucosa.Gut;47:762-770.

42. Mizuno,H.; Sakamoto, C.; Matsuda, K.; Wada, K.; Uchida, T.; Noguchi, H.; Akamatsu, T. and Kasuga, M. (1997): Induction of cyclooxygenase 2 in gastric mucosal lesions and its inhibition by the specific antagonist delays healing in mice. Gastroenterology 112:387-397.

43. Konturec, P.; Kania, J.; Hahn, E. and Konturek, J. (2006): Ascorbic acid attenuates aspirin-induced gastric damage: role of inducible nitric oxide synthase. J Physiol Pharmacol; 57:125-136.

44. Jainu, M. and Devi, C. (2006): Gastroprotective action of Cissus quadrangularis extract against NSAID induced gastric ulcer: role of pro-inflammatory cytokines and oxidative damage. Chem Biol Interact; 161: 262-270.

45. Chen, C.; Rose, R. and Ho, C. (1986): Chromatographic analysis of isometric shogaol compounds derived from isolated gingerol compounds of ginger(Zingiber Officinale Roscope ). J.Chromatogr; 360: 175-184.

46. Sakr, S.A., (2011): Ameliorative effect of ginger (Zingiber officinale) on mancozeb fungicide induced liver injury in albino rats. Australian J. Basic Appl. Sci., 1(14): 650-656

47. Akinola, A.; Syahida, A. and M. Mahamood, (2014): Total anti-oxidant capacity, flavonoid, phenolic acid and polyphenol content in ten selected species of Zingberaceae rhizomes. African J. of Traditional, Complementary and Alternative Medicines, 11(3): 7-13. 
الملخص العربى

\section{دراسة بالمجهر الضوئي والاككتروني على التأثير الوقائي المحتمل للزنجبيل على الغثاء

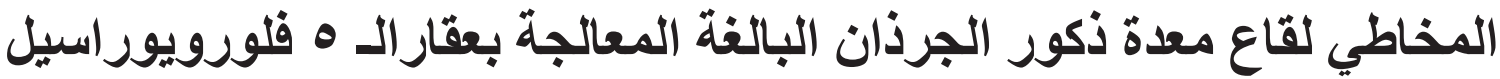

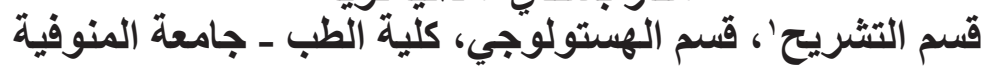

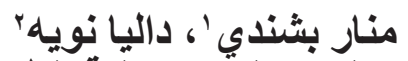

المقدمة: -5 فلورويور اسيل هو دو اء يستخدم في العلاج الكيميائي لمختلف الأور ام الخبيثة مثل سرطان الثذي، القولون و المستقيم ، وسرطان الكبد. استخدام هذا العلاج يؤدي إلى تأثيرات ضارة وسامة مثل القيء والاسهال ، التهاب الغشاء المخاطي في بطانة الجهاز الهضمي. لتحسين الاثار الجانبية ل-5 فلورويور اسيل تم عمل هذه الدر اسة باستخدام الزنجبيل. الهرف من البحث: لتقييم التأثثير ات السلبية المجهرية لعقار -5 فلورويور اسيل على الغثاء المخاطي لقاع المعدة باستخدام نماذج ذكور الفئران. وتوضيح أيضًا الدور المفيد المحتمل للزنجبيل في تحسين هذه التغييرات. المواد والطرق المستخدمة: تم اختيار ثمان و أربعين من ذكور الجرذان البالغة وقسمت إلى أربع مجموعات: المجموعة الأولى (الضابطة) ، و المجموعة الثانية (المعالجة بالزنجبيل) تم اعطائها الزنجبيل بالفم بجر عة 200 ملغم / كغم من وزن الجسم في اليوم ، المجموعة الثالثة (المعالجة ب5 فلورويور اسيل ) تلقت -5فلورويور اسيل بجرعة مقدارها 15ملغم / كغم عن طريق الحقن داخل الغشاء البريتوني و المجموعة الرابعة (5 ـفلورويور اسيل و الزنجبيل) تلقى 5 ـفلورويور اسيل و الزنجبيل بنفس الجرعات السابقة لمدة 5 أيام. تم استنُصسال الجزء المخروطي من المعدة وتعرض لدر اسة نسيجية ، ونسجو مناعية ، ودر اسة هيستو -مورفومترية ودر اسة بو اسطة الميكروسكوب الالكتروني لدر اسة التركيب الداخلي الدقيق . النتائج: في المجموعة المعالجة بعقار -5 فلورويور اسيل أظهر الغشاء المخاطي لقاع المعدة مناطق متعددة من فقدان الأنسجة مع الاتساع بين الغدد ، وتمدد الأوعية الدموية وتناثرخلايا الدم الحمر اء بين الغدد الموجودة بقاع المعدة و أيضاً تو اجد الخلايا المسئولة عن الالتهابات ــ اظهرت الخلايا الجدارية و الخلايا الرئيسية تغير ات في النواة والسيتوبلازم ـ و أظهرت المقاطع المصبو غة بصبغة الثيف الحامضية والالثيان انخفاض ملحوظ في كمية المخاط و ايجابية لصبغة الثيف الحامضية. باستخدام الصبغات المناعية ، كان هناك رد فعل قوي في الأجز اء الموجودة في اعلي ووسط الغدد المتو اجدة بقاع المعدة و ذلك باستخدام كسباس 3في حين ان الخلايا الجدارية هي التي اظهرت إيجابية للانتيكوكس II. تم تحسين هذه النتائج النسيجية بعد استخدام الزنجبيل. وكثفت الدر اسة المورفومترية انخفاض كبير في الوزن ، وزيادة عمق قرحة الغشاء المخاطي ، و انخفاض سمك الغشاء المخاطي و انخفاض في اعداد الخلايا الجدارية في المجمو عة المعالجة ب -5 فلورويور اسيل بالمقارنة مع المجموعة الضابطة. الاستنتاج : عقار 5 - فلورويور اسيل يسبب تلف المعدة في نموذج الفئران. يمكن استخدام الزنجبيل للتخفيف من التأثير المرضي الضار على قاع المعدة. ومن الممكن ادخاله في النظام الغذائي للوقاية من اصابات و أمر اض المعدة. 